\title{
Vroegchristelike eksegese van Johannes
}

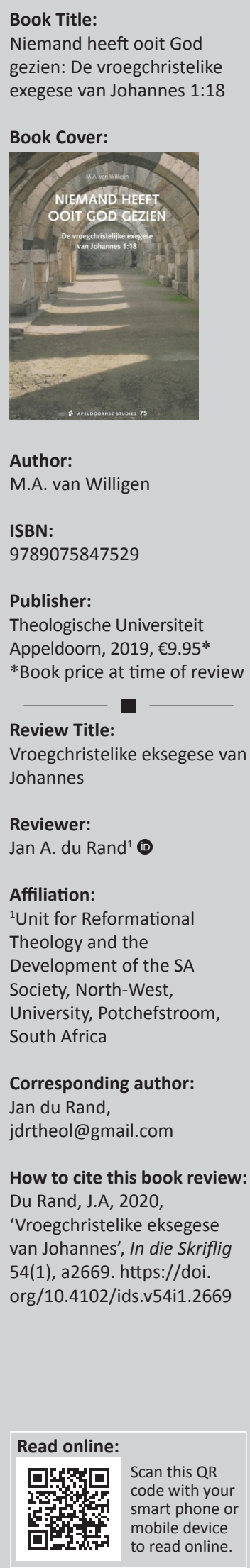

Author:

M.A. van Willigen

ISBN:

9789075847529

Publisher:

Theologische Universiteit Appeldoorn, 2019, €9.95*

*Book price at time of review

Review Title:

Vroegchristelike eksegese van Johannes

Reviewer:

Jan A. du Rand ${ }^{1}$ (D)

\section{Affiliation:}

${ }^{1}$ Unit for Reformational

Theology and the

Development of the SA

Society, North-West,

University, Potchefstroom,

South Africa

\section{Corresponding author:}

Jan du Rand,

jdrtheol@gmail.com

How to cite this book review: Du Rand, J.A, 2020,

'Vroegchristelike eksegese

van Johannes', In die Skriflig

54(1), a2669. https://doi.

org/10.4102/ids.v54i1.2669

Read online:

Scan this QR
code with your
smart phone or
mobile device
to read online.

Bogenoemde publikasie is die skriftelike weergawe van die intreerede deur prof. dr. Van Willigen as hoogleraar in Bijbeluitleg Vroege Kerk aan die Theologische Universiteit Apeldoorn op 20 Junie 2019.

In 'n sistematiese en wetenskaplik-verantwoorde uiteensetting, behandel prof. Van Willigen as inleiding die vraag na die noodsaaklikheid van 'n leerstoel in Bijbeluitleg Vroege Kerk. Hierdie vraag hang saam met hernude teologiese belangstelling in die vroeë Christelike kerk. Op oortuigende wyse regverdig prof. Van Willigen die waarde van die navorsing oor die Vroeë Kerk. Dit word opgevolg deur die grondige navorsingsvraag te vra, naamlik of die uitleg van vroegchristelike brontekste waarde vir die Teologie het. Die wesenlike waarde word voorts geillustreer deur Johannes 1:18 as voorbeeld te bespreek. Dit is uiteraard 'n ingewikkelde teks. Volgens ateïste is die vraag 'n waar stelling; die gnostici en die Jode sien die vraag in eie lig. Selfs Moses het God nie gesien nie. Met 'n kritiese oog kyk Van Willigen verder na preke deur Augustinus (354-430) en Chrysostomus (349-407) oor Johannes 1:18. Dit is insiggewende leesstof om by albei te verneem dat Christus op 'n heel ander vlak as Moses beskryf word. Jesus Christus, die Seun van God, is wel gesien, maar nie deur die Jode en heidene aanvaar nie. Dit is nie nuwe uitsprake nie, maar stimulerend om Augustinus en Chrysostomus se worsteling met Johannes 1:18 te beleef. Van Willigen se antwoord daarop is Christologies verantwoord, met die gevolgtrekking dat hedendaagse teologie veel by Augustinus en Chrysostomus te leer het. Ek vind prof. Van Willigen se eie uitleg inspirerend, veral omdat hy Skrif met Skrif vergelyk wanneer hy 1 Johannes 4:12 bybring, asook Augustinus se aangrypende behandeling van 1 Johannes 3:2. As bonus tot die intreerede word 'n preek van Augustinus oor Johannes 1:16-18 bygevoeg. Dit was vir my 'n leesfees. Augustinus baken nie die teks af binne ko-tekstuele verband (soos ons vandag sou doen) nie, maar plaas die stelling eerder dadelik in sy groter teologiese verband. Dit is opvallend dat Augustinus ook aan filosofiese waarhede raak wanneer hy die wysheid van God in sy preek bespreek.

Prof. Van Willigen word met die aanvaarding van die leerstoel, asook met die uiters lesenswaardige publikasie van sy intreerede gelukgewens. 'n Groot waardering ook vir die plasing van die besielende preek van Augustinus oor Johannes 1:15-18 as Addendum. 